\title{
Coronary Sinus Reducing Stent for the Treatment of Refractory Angina Pectoris: A Health Technology Assessment
}

This article was published in the following Dove Press journal: Medical Devices: Evidence and Research

\author{
Michal Stanak' \\ Eleen Rothschedl' \\ Piotr Szymanski $\mathbb{D}^{2}$ \\ 'Austrian Institute for Health Technology \\ Assessment (AlHTA), Vienna, Austria; \\ ${ }^{2}$ MSWiA Central Clinical Hospital, \\ Centre of Postgraduate Medical \\ Education, Warsaw, Poland
}

\begin{abstract}
Aim: To summarize the evidence on the clinical effectiveness and safety of coronary sinus reducing stent (CSRS) therapy in refractory angina pectoris (AP) patients.

Methods: We performed a systematic literature search in common databases $(n=4)$. The evidence obtained was summarized according to GRADE methodology. A health technology assessment (HTA) was conducted using the HTA Core Model ${ }^{\circledR}$ for Rapid Relative Effectiveness Assessment. Primary outcomes for the clinical effectiveness domain were the proportion of patients with improvement in two or more Canadian Cardiovascular Society (CCS) angina score classes, overall mean reduction of CCS class, and Seattle Angina Questionnaire (SAQ) quality of life (QoL) score improvement. Outcomes for the safety domain were adverse device effects (ADEs) and serious adverse device effects (SADEs).

Results: One randomized controlled trial (RCT) was identified. Outcomes that showed statistically significant differences between CSRS and sham treatment (in favor of CSRS) were CCS angina score improvement of one or two classes, overall mean reduction of CCS class, and SAQ QoL score improvement. Concerning safety, the sham-controlled trial data indicate that there were fewer SADEs in the intervention group (19\%) than in the control group (46\%). SADEs reported in observation studies ranged from none to $30 \%$. The most frequently reported SADEs were death and stable angina. In the RCT, the only case of death occurred in the control group. Concerning clinical effectiveness, the risk of bias (RoB) was rated to be low, and concerning safety, the $\mathrm{RoB}$ was rated to range from low to moderate. As assessed by GRADE, the overall strength of evidence for effectiveness and safety was moderate. Internal and external validity of the evidence base were low.
\end{abstract}

Conclusion: Even though the current evidence indicates that the assessed technology, CSRS, is potentially more effective than sham intervention for refractory AP patients, the lack of internal validity of the studies undermines the partially positive results.

Keywords: refractory angina pectoris, coronary artery disease, coronary sinus reducing stent, coronary sinus

\section{Introduction}

Cardiovascular disease at large is a major cause of health loss across all regions of the world. ${ }^{1}$ The Global Burden of Disease project 2015 estimated that 442.7 million prevalent cases of cardiovascular disease were present worldwide, which caused an estimated 17.92 million deaths. ${ }^{1}$ Ischemic heart disease was one of the leading causes of all health loss globally. ${ }^{1}$ Exact estimates of the incidence and prevalence of refractory angina pectoris (AP) are not available, but a guessed estimate by the 2002 European Society of Cardiology (ESC) Joint Study Group suggests that refractory AP occurs in $5-10 \%$ of
Correspondence: Michal Stanak Austrian Institute for Health Technology Assessment, Garnisongasse 7/20, Vienna 1090, Austria

Email michal.stanak@protonmail.com
Medical Devices: Evidence and Research 2020:13 259-276 
all AP patients. ${ }^{2}$ Refractory AP is conventionally defined as a chronic condition ( $\geq 3$ months in duration) characterized by angina in the setting of ischemic heart disease, which cannot be controlled by a combination of optimal medical therapy, angioplasty, or bypass surgery, and where reversible myocardial ischemia has been clinically established to be the cause of the symptoms. $^{2}$ The estimated incidence of newly diagnosed patients with refractory angina in the USA ranges between 50,000 and 100000 per year, while in Europe, the incidence is estimated to range between 30,000 and 50,000 new cases per year. $^{3}$

The coronary sinus reducing stent (CSRS) aims to treat refractory AP patients and is suggested to be put in place once all the other therapeutic options are exhausted. Except for palliative management, the only alternative option for refractory AP that is based on controlled evidence is external counterpulsation. ${ }^{4,5}$

According to the ESC 2019 guideline, CSRS received the recommendation $2 \mathrm{~b}$, which means that the usefulness of CSRS is less well established by evidence/opinion, but that it may be considered for use in clinical practice. ${ }^{5}$ There is also limited information on the effectiveness and safety of the CSRS, which would be published in the form of health technology assessment (HTA) reports. ${ }^{6,7}$ For our assessment, we used the European Network for Health Technology Assessment (EUnetHTA) Core Model ${ }^{\circledR}$ for rapid Relative Effectiveness Assessment (REA), which is used for assessing the clinical effectiveness and safety of pharmaceuticals, diagnostic technologies, medical and surgical interventions, and screening technologies. We used this model to evaluate the clinical effectiveness and safety of CSRS therapy in refractory AP patients.

\section{Methods}

\section{Systematic Literature Search}

We conducted a systematic literature search on 10-13 December 2019 in four databases (Medline via Ovid, Embase, The Cochrane Library, and CRD [DARE, NHSEED, HTA]) without a limit to years of publication, but limited to German and English. We searched for published clinical studies on CSRS in refractory AP patients. The search strategies can be provided upon request. In order to identify ongoing and unpublished studies, we conducted a search in three clinical trials registries (ClinicalTrials.gov, WHO-ICTRP, and EU Clinical Trials) on 29-30 January 2020 , resulting in 13 potentially relevant hits.

\section{Study Selection and Internal Validity Assessment}

The inclusion criteria for the literature selection were defined using the Population-Intervention-ComparisonOutcome-(Study design) model (PICOs) shown in Table 1. No limit was set on the minimum number of study participants, but individual case reports were excluded. Two researchers selected references for inclusion and systematically extracted relevant studies into data-extraction tables. Internal validity was assessed using the risk of bias (RoB) tool for RCTs of the Cochrane Collaboration, ${ }^{8}$ as well as by the checklist for single-arm studies of the Institute of Health Economics (IHE). ${ }^{9}$ No cases of disagreement occurred.

\section{Outcome Measures}

Outcomes were selected in accordance with EUnetHTA guidelines for rapid REAs, which state that clinical endpoints relevant for patients should be selected whenever possible (mortality, morbidity, health-related quality of life, and treatment satisfaction). Primary outcomes for clinical effectiveness were: Canadian Cardiovascular Society (CCS) angina score improvement of one or two classes, overall mean reduction of CCS class, and Seattle Angina Questionnaire (SAQ) quality of life (QoL) score improvement. For the assessment of safety, adverse device effects (ADEs) and serious adverse device effects (SADEs) were included.

\section{Synthesis of Evidence}

The Grading of Recommendations, Assessment, Development and Evaluation (GRADE) methodology was used for summarizing and evaluating the strength of the evidence. ${ }^{11}$ Categories of high, moderate, low, and very low were applied and only critical outcomes were assessed. No meta-analysis was performed as only one prospective controlled trial was identified.

\section{Methodological Framework and Reporting}

An adaptation of the EUnetHTA Core Model for REAs was used for this HTA. The generic questions from Core Model (version 4.2) were translated into actual research questions. This analysis was reported based on the Preferred Reporting Items for Systematic Reviews and Meta-Analyses (PRISMA) statement. ${ }^{12}$ 
Table I PICOs Inclusion Criteria

\begin{tabular}{|c|c|}
\hline Population & $\begin{array}{l}\text { Heavily pretreated adult patients ( } \geq 18 \text { years of age) with } \\
\text { coronary artery disease (CAD) who are not candidates } \\
\text { for revascularization demonstrate reversible ischemia, } \\
\text { and have refractory angina pectoris despite standard } \\
\text { medical therapy. } \\
\text { ICD-I0 Code: } 120.9 \\
\text { MeSH terms: Heart, Heart Diseases, Myocardial } \\
\text { Ischemia, Coronary Artery Disease, Angina Pectoris }\end{array}$ \\
\hline Intervention & $\begin{array}{l}\text { Coronary-sinus reducing device/stent made of } \\
\text { stainless steel is implanted in the coronary sinus and } \\
\text { pre-mounted on a customized hourglass-shaped } \\
\text { balloon catheter. The catheter is inserted into its } \\
\text { place via the jugular vein under local anesthesia } \\
\text { Available agent: Neovasc Reducer }{ }^{T M} \text { System (Neovasc } \\
\text { Inc, British Columbia, Canada) MeSH terms: } \\
\text { Percutaneous Coronary Intervention, Stents }\end{array}$ \\
\hline Control & $\begin{array}{l}\text { Sham procedure } \\
\text { MeSH terms: NA }\end{array}$ \\
\hline Outcomes & \\
\hline Efficacy & $\begin{array}{l}\text { Clinical endpoints: } \\
\text { CCS angina score } \\
\text { SAQ for QoL } \\
\text { SAQ for treatment satisfaction } \\
\text { Surrogate endpoints: } \\
\text { Exercise tolerance as assessed with the use of a } \\
\text { symptom-limited stress test } \\
\text { ST-segment depression during exercise } \\
\text { Modified Wall Motion Score Index } \\
\text { Antianginal medication intake }\end{array}$ \\
\hline Safety & $\begin{array}{l}\text { Serious adverse device effects (SADEs) } \\
\text { Adverse device effects (ADEs) }\end{array}$ \\
\hline Study design & \\
\hline Efficacy & $\begin{array}{l}\text { Randomized controlled trials (RCTs) } \\
\text { Prospective non-randomized controlled trials (NRCTs) }\end{array}$ \\
\hline Safety & $\begin{array}{l}\text { Randomized controlled trials (RCTs) } \\
\text { Prospective non-randomized controlled trials (NRCTs) } \\
\text { Prospective case series (single-arm studies, registries, etc.) } \\
\text { (No minimum number of patients required, but individual } \\
\text { case reports excluded) }\end{array}$ \\
\hline
\end{tabular}

Note: Reproduced with permission from Stanak M., Rothschedl E. Percutaneous Transvascular Implantation of a Coronary Sinus Reducing Stent. Systematic Review. Decision Support Document No. I21; 2020. Vienna: Ludwig Boltzmann Institute for Health Technology Assessment. Available from: https://eprints.aihta.at//256/1/ DSD_I21.pdf. ${ }^{10}$

\section{Results}

\section{Search Results}

Through a systematic search, we found 349 relevant citations. An additional 14 were found by a hand search, which resulted in overall 363 hits. The specific search strategy employed can be provided by the authors upon request. Concerning clinical effectiveness, one randomized controlled trial $(\mathrm{RCT})^{13}$ met the inclusion criteria. Concerning safety, seven studies met the inclusion criteria: one RCT used also in the clinical effectiveness assessment ${ }^{13}$ and six prospective observational non-comparative studies. ${ }^{14-19}$ No retrospective study was included in the assessment. All the extracted data can be found in Tables 2, 3, and 4 .

\section{Study and Patient Characteristics Study Characteristics}

Concerning clinical effectiveness, one controlled trial was found (an RCT) that compared CSRS with a sham procedure (study name COSIRA, NCT01205893) and was sponsored by the manufacturer Neovasc Inc. ${ }^{13}$ It was conducted between April 2010 and April 2013 in 11 centers (in Belgium, Canada, Denmark, the Netherlands, Sweden, and the UK). The RCT included 104 patients (52 were in the intervention group [IG] and 52 in the control group [CG]) and the patient population was followed for 6 months. No patient was lost to follow-up.

Concerning safety, seven studies met the inclusion criteria. One RCT, described above, ${ }^{13}$ four prospective case series, ${ }^{14-16,19}$ and two prospective registries. ${ }^{17,18}$ The total number of patients analyzed in safety analysis who received the CSRS therapy was 348 (plus 52 patients in CG). The observational studies were conducted between October 2004 and April 2017 in Germany, India, Israel, Italy, and Belgium. The follow-up ranged from $4^{14}$ to 24 months. ${ }^{15}$ No observational study stated the source of funding.

\section{Patient Characteristics}

In the RCT included in the assessment of clinical effectiveness analysis, patients were evenly distributed between the IG and CG. All patients belonged to CCS angina class III or IV, despite attempted optimal pharmacological therapy for 30 days prior to screening, and all had evidence of reversible ischemia with limited options for revascularization. Mean left ventricular ejection fraction (LVEF) ranged between $53.5 \%$ and $54.8 \%$. Most of the patients had experienced the following conditions or received the following interventions: previous coronary artery bypass grafting $(\mathrm{CABG})$, previous percutaneous coronary intervention (PCI), previous myocardial infarction (MI), current/previous smoking, diabetes mellitus, hypertension, 
Table 2 CSRS: Results from RCTs

\begin{tabular}{|c|c|}
\hline Authors (Year) & Verheye et $\mathrm{al}^{13}(2015)$ \\
\hline Country & II clinical centers (Belgium, Canada, Denmark, Netherlands, Sweden, UK) \\
\hline Sponsor & Neovasc Inc. \\
\hline Study design & $\begin{array}{l}\text { Multi-center, prospective, double-blinded, randomized, sham-controlled, Phase } 2 \text { trial (COSIRA, } \\
\text { NCTO I205893) }\end{array}$ \\
\hline Conducted in & $04 / 2010-04 / 2013$ \\
\hline Indication & $\begin{array}{l}\text { Refractory AP despite standard medical therapy (pts with CAD, no candidates for } \\
\text { revascularization, reversible ischemia) }\end{array}$ \\
\hline Intervention (I) & Coronary-sinus reducing stent (Reducer) \\
\hline Comparator (C) & Sham procedure: no stent implanted \\
\hline Number of pts (I vs C) & $52^{\mathrm{a}}$ vs 52 \\
\hline Inclusion criteria & $\begin{array}{l}\text { Pts } \geq 18 \text { years of age, symptomatic CAD pts with chronic refractory AP grade III or IV (classified } \\
\text { by CCS) despite attempted optimal medical therapy for } 30 \text { days prior to screening, limited } \\
\text { treatment options for revascularization by CABG or PCl, evidence of reversible ischemia } \\
\text { attributable to the left coronary arterial system by dobutamine Echo, LVEF }>25 \% \text {, informed } \\
\text { consent, compliance with follow-up }\end{array}$ \\
\hline Exclusion criteria & $\begin{array}{l}\text { Pregnancy, acute coronary syndrome in }<3 \text { mos, } \mathrm{CABG} / \mathrm{PCl} \text { in }<6 \text { mos, unstable angina (recent- } \\
\text { onset angina, crescendo angina, or rest angina with } \mathrm{ECG} \text { changes) in }<1 \text { month prior to screening, } \\
\text { decompensated CHF or hospitalization due to CHF during } 3 \text { mos prior to screening, } \\
\text { lifethreatening rhythm disorders or any rhythm disorders that would require placement of an } \\
\text { internal defibrillator and/or pacemaker, severe COPD as indicated by a forced expiratory volume } \\
\text { in one second that is less than } 55 \% \text { of the predicted value, pts unable to undergo exercise } \\
\text { tolerance test (bicycle) for reasons other than refractory AP, severe valvular heart disease, } \\
\text { pacemaker or defibrillator electrode in the right atrium, right ventricle, or coronary sinus, } \\
\text { tricuspid valve replacement or repair, chronic renal failure (serum creatinine }>2 \mathrm{mg} / \mathrm{dL} \text { ) with } \\
\text { patients on chronic hemodialysis, moribund pts, pts with comorbidities limiting life expectancy to } \\
<\text { I yr, contraindication to required study medications that cannot be adequately controlled with } \\
\text { pre-medication, allergy to stainless steel or nickel, contraindication } \\
\text { to having an MRI performed, enrollment in another investigational device or drug trial that has } \\
\text { not completed the primary endpoint or that clinically interferes with the current study endpoints, } \\
\text { mean right atrial pressure } \geq 15 \mathrm{mmHg} \text {, anomalous or abnormal CS as demonstrated by angiogram } \\
\text { (abnormal CS anatomy - tortuosity, aberrant branch, persistent left SVC) and/or; CS diameter at } \\
\text { the site of planned reducer implantation }<9.5 \mathrm{~mm} \text { or }>13 \mathrm{~mm}\end{array}$ \\
\hline Primary outcome measure & $\begin{array}{l}\text { Proportion of pts with improvement in } 2 \text { or more CCS angina score classes from baseline to } 6 \text { - } \\
\text { mo follow-up }\end{array}$ \\
\hline Secondary outcome measure & $\begin{array}{l}\text { Technical and procedural success measured at } 24 \mathrm{hrs} \\
\text { Measured at } 30 \text {-day follow-up: } \\
\text { - Periprocedural AEs and SAEs (death, MI, cardiac tamponade, life-threatening arrhythmia, and } \\
\text { respiratory failure)Measured at 6-mo follow-up: } \\
\text { - Proportion of pts with improvement of one or more CCS angina score classes } \\
\text { - Exercise tolerance assessed with the use of a symptom-limited stress test } \\
\text { - SAQ Score } \\
\text { - Dobutamine echo WMSI } \\
\text { - Major AEs (cardiac death, major stroke, and MI) }\end{array}$ \\
\hline
\end{tabular}

(Continued) 
Table 2 (Continued).

\begin{tabular}{|c|c|}
\hline Verheye et al $^{13}(2015)$ & Verheye et $\mathrm{al}^{13}(2015)$ \\
\hline \multicolumn{2}{|l|}{ Baseline patient characteristics (I vs C) (intention-to-treat) } \\
\hline Mean age, yrs ( \pm SD) & $69.6(8.7)$ vs $66.0(9.8)$ \\
\hline Sex, female:male, $n$ & $8: 44$ vs $12: 40$ \\
\hline Previous MI, n (\%) & $27(52)$ vs $30(58)$ \\
\hline Previous CABG, n (\%) & $42(8 I)$ vs $38(73)$ \\
\hline Previous PCI, n (\%) & $36(69)$ vs 40 (77) \\
\hline Hypercholesterolemia, n (\%) & $50(96)$ vs $46(88)$ \\
\hline Diabetes mellitus, n (\%) & 21 (40) vs 25 (48) \\
\hline Hypertension, n (\%) & $42(8 I)$ vs $4 I$ (79) \\
\hline Current or previous smoking, n (\%) & $27(52)$ vs 31 (60) \\
\hline \multicolumn{2}{|l|}{ CCS angina class, $n(\%)$} \\
\hline Class III & $42(8 \mathrm{I})$ vs $45(87)$ \\
\hline Class IV & $10(19)$ vs $7(13)$ \\
\hline Mean LVEF, n (士SD) & $53.5(10.2)$ vs $54.8(11.9)$ \\
\hline \multicolumn{2}{|l|}{ No. of antianginal medications ${ }^{b}, n(\%)$} \\
\hline 0 & $3(6)$ vs $4(8)$ \\
\hline 1 & $10(19)$ vs $10(19)$ \\
\hline 2 & $23(44)$ vs I8 (35) \\
\hline 3 & $12(23)$ vs $18(35)$ \\
\hline$>3$ & $4(8)$ vs $2(4)$ \\
\hline Follow-up time, mos & 6 \\
\hline Loss to follow-up, \% & 0 \\
\hline \multicolumn{2}{|l|}{ Efficacy (I vs C) } \\
\hline \multirow[t]{2}{*}{ CCS angina score improvement of at least 2 classes at 6 mos, $n(\%)$} & $18(35)$ vs $8(15)$ \\
\hline & $p=0.02$ \\
\hline \multirow[t]{2}{*}{ CCS angina score improvement of at least I class at 6 mos, $n$ (\%) } & 37 (7I) vs $22(42)$ \\
\hline & $p=0.003$ \\
\hline \multirow{2}{*}{$\begin{array}{l}\text { Reduction in CSS class, mean n (SD), (baseline/6 mos) } \\
\text { Difference, } n\end{array}$} & $3.2(0.4) / 2.1(1.0)$ vs $3.1(0.3) / 2.6(0.9)$ \\
\hline & $p=0.001$ \\
\hline & I.I vs 0.5 \\
\hline \multirow[t]{2}{*}{ SAQ QoL score improvement, $n$ of points } & 17.6 vs 7.6 \\
\hline & $p=0.048$ \\
\hline \multirow{2}{*}{$\begin{array}{l}\text { SAQ treatment satisfaction, mean difference baseline/follow-up } \\
( \pm S D), n \text { of points }\end{array}$} & $2.9(16.6)$ vs $2.9(15.8)$ \\
\hline & $p=0.981$ \\
\hline \multirow[t]{2}{*}{ Total exercise duration improvement, $\mathbf{n}$ of seconds (\%) } & 59 (I3) vs 4 (I) \\
\hline & $p=0.07$ \\
\hline WMSI improvement, \% & 14 vs $8 p=0.20$ \\
\hline \multicolumn{2}{|l|}{ Safety (I vs C) } \\
\hline Total SADEs, $n$ & 10 vs $24^{c}$ \\
\hline MI, n (\%) & I (2) vs $3(6)^{d}$ \\
\hline Stable angina, $\mathrm{n}(\%)$ & I (2) vs $5(10)$ \\
\hline Crohn's disease flare, n (\%) & I (2) vs $0(0)$ \\
\hline Unstable angina, n (\%) & I (2) vs 4 (8) \\
\hline Epigastric pain, n (\%) & $0(0)$ vs I (2) \\
\hline Atypical chest pain, n (\%) & I (2) vs 6 (I2) \\
\hline
\end{tabular}


Table 2 (Continued).

\begin{tabular}{|c|c|}
\hline Authors (Year) & Verheye et $\mathrm{al}^{13}(2015)$ \\
\hline Acute coronary syndrome, $\mathrm{n}(\%)$ & $0(0)$ vs $2(4)$ \\
\hline Arrhythmia, n (\%) & $0(0)$ vs I (2) \\
\hline Multi-system failure/death, n (\%) & $0(0)$ vs I (2) \\
\hline Pulmonary edema, n (\%) & $0(0)$ vs I (2) \\
\hline COPD, n (\%) & I (2) vs I (2) \\
\hline Cough, n (\%) & $0(0)$ vs I (2) \\
\hline Decompensated heart failure, $\mathrm{n}(\%)$ & I (2) vs $0(0)$ \\
\hline Gastrointestinal bleeding, n (\%) & I (2) vs $0(0)$ \\
\hline Injury, n (\%) & I (2) vs $0(0)$ \\
\hline Bleeding events associated with dual antiplatelet therapy & NA \\
\hline ADEs (at least I AE in $n$ of pts (\%)) & $32^{\mathrm{e}}(64)$ vs $37^{f}(69)$ \\
\hline
\end{tabular}

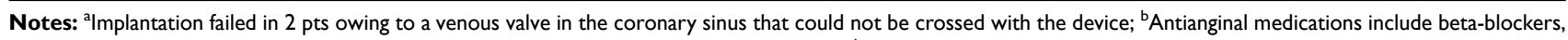

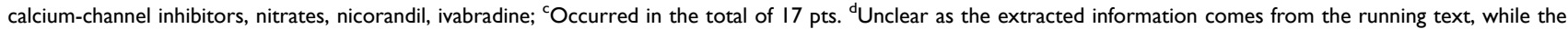
Table 5 in Appendix states that one case of Ml occurred in IG as well as CG; ${ }^{\mathrm{e}}$ Out of 50 pts. Total of 76 AEs reported in IG; ${ }^{\mathrm{f}}$ Out of 54 pts. Total of 93 AEs reported in the control group.

Abbreviations: ADE, adverse device effect; AP, angina pectoris; C, control; CABG, coronary artery bypass grafting; CAD, coronary artery disease; CCS, Canadian Cardiovascular Society; CG, control group; CHF, congestive heart failure; COPD, chronic obstructive pulmonary disease; CS, coronary sinus; ECG, electrocardiogram; hrs, hours; I, intervention; IG, intervention group; LVEF, left ventricular ejection fraction; MI, myocardial infarction; mos, months; n, number; NA, not available; MRI, magnetic resonance imaging; PCl, percutaneous coronary intervention; pts, patients; QoL, quality of life; SADE, serious adverse device effect; SAQ, Seattle Angina Questionnaire; SD, standard deviation; WMSI, Wall Motion Score Index; yr, year.

hypercholesterolemia, and intake of one or more antianginal medications. ${ }^{13}$ Exclusion criteria were highly specific and are presented in detail in Tables 2, 3, and 4.

In the trials included in the assessment of safety, all patients belonged to CCS angina classes II-IV and had an LVEF of more than $25 / 30 \%$. Inclusion criteria in all prospective observational studies were homogeneous with respect to the definition of severe refractory AP despite pharmacological therapy, ineligibility for $\mathrm{CABG}$ and/or PCI, and objective myocardial ischemia. Exclusion criteria were more heterogeneous, as three observational studies excluded patients with $\mathrm{MI}$ and $\mathrm{CABG} /$ $\mathrm{PCI}$ in less than 3 (to 7) months and patients with the presence of life-threatening arrhythmias, decompensated heart failure, and severe valvular heart disease. ${ }^{16,17,19}$ While tricuspid valve replacement/repair was an exclusion criterion in two studies, ${ }^{16,19}$ presence of a pacemaker lead was an exclusion criterion in four studies, ${ }^{15,16,18,19}$ acute coronary syndrome in less than 3 months was an exclusion criterion in three studies, ${ }^{14,15,18}$ and right atrial pressure of more than or equal to $15 \mathrm{mmHg}$ was a criterion in all studies. ${ }^{14-19}$

\section{Clinical Effectiveness}

Data from the only controlled trial found (an RCT) served as the only source for reporting on clinical effectiveness outcomes and were reported at the 6-month follow-up. ${ }^{13}$ No longer-term data were found and so no results on progression and/or recurrence are present. Concerning the outcome of mortality, one case of SADE of death was reported in the RCT. It occurred in the CG, while no cases of death occurred in the IG. Concerning morbidity, the outcome of CCS angina score improvement of at least two classes occurred in $35 \%$ of IG and $15 \%$ of CG patients $(p=0.02)$. CCS angina score improvement by one class occurred in $71 \%$ of IG and $42 \%$ of CG patients $(p=0.003)$, and the overall mean reduction of CCS class was 1.1 classes in the IG and 0.5 classes in the CG $(p=0.001)$.

In terms of the effect of CSRS on the patient's body functions, two outcomes were considered relevant: Wall Motion Score Index (WMSI) improvement and total exercise duration improvement. While the WMSI improved by $14 \%$ in the IG and $8 \%$ in the CG $(p=0.20)$, the total exercise duration improved by 59 seconds $(13 \%)$ in the IG and by 4 seconds $(1 \%)$ in the CG $(p=0.07)$.

Disease-specific QoL was reported with respect to improvement in SAQ QoL score, and while IG patients improved by 17.6 points, CG patients improved by 7.6 points $(p=0.048)$. Patient satisfaction was reported with respect to SAQ treatment satisfaction score, which improved by a mean of 2.9 points in both the IG and the CG. See Table 2 for further details.

\section{Safety}

\section{Comparative Studies}

In the only RCT, ${ }^{13} 10(19 \%)$ SADEs occurred in the IG as opposed to 24 (46\%) in the CG, and no SADEs occurred with more frequency in the IG than the CG. Almost all cases of 
Table 3 CSRS: Results from Observational Studies (Part I)

\begin{tabular}{|c|c|c|c|}
\hline Authors (Year) & Banai et al ${ }^{19}(2007)$ & Giannini et $\mathrm{al}^{20}(20 \mid 8)$ & Konigstein et al ${ }^{16}(2014)$ \\
\hline Country & Germany, India, Israel & Italy, Israel, Belgium & Israel, Belgium \\
\hline Sponsor & Neovasc Inc. & Neovasc Inc. & Neovasc Inc. \\
\hline Study design & $\begin{array}{l}\text { Multicenter, open-label, } \\
\text { prospective, safety and feasibility, } \\
\text { first-in-man case series }\end{array}$ & $\begin{array}{l}\text { Multicenter, prospective }{ }^{\text {a }} \text {, single- } \\
\text { arm, non-blinded registry study }\end{array}$ & Multicenter, prospective case series \\
\hline Conducted in & I0/2004-07/2005 & $09 / 2010-04 / 2017$ & NA \\
\hline Indication & $\begin{array}{l}\text { Refractory AP despite standard } \\
\text { medical therapy (pts with CAD, } \\
\text { reversible ischemia, no candidates } \\
\text { for revascularization) }\end{array}$ & $\begin{array}{l}\text { Refractory AP despite standard } \\
\text { medical therapy (pts with CAD, } \\
\text { reversible ischemia, no candidates } \\
\text { for revascularization) }\end{array}$ & $\begin{array}{l}\text { Refractory AP despite standard } \\
\text { medical therapy (pts with CAD, } \\
\text { reversible ischemia, no candidates } \\
\text { for revascularization) }\end{array}$ \\
\hline Intervention & $\begin{array}{l}\text { Coronary-sinus reducing stent } \\
\text { (Reducer) }\end{array}$ & $\begin{array}{l}\text { Coronary-sinus reducing stent } \\
\text { (Reducer) }\end{array}$ & $\begin{array}{l}\text { Coronary-sinus reducing stent } \\
\text { (Reducer) }\end{array}$ \\
\hline Comparator & None & None & None \\
\hline Number of pts & $15^{b}$ & $|4|$ & $23^{c}$ \\
\hline Inclusion criteria & $\begin{array}{l}\text { Symptomatic CAD, refractory } \\
\text { angina - CCS class II-IV despite } \\
\text { medical therapy, pts not eligible for } \\
\text { CABG or PCl, reversible } \\
\text { myocardial ischemia (determined by } \\
\text { perfusion scan and/or by } \\
\text { dobutamine ECG), LVEF } \geq 30 \%\end{array}$ & $\begin{array}{l}\text { Obstructive CAD, chronic disabling } \\
\text { AP (CCS class II-IV) despite } \\
\text { maximally tolerated medical therapy, } \\
\text { pts not eligible for CABG or PCl, } \\
\text { objective demonstration of ischemia } \\
\text { with either treadmill/pharmacological } \\
\text { stress test, myocardial stress } \\
\text { scintigraphy, stress ECG, or MI, } \\
\text { consent }\end{array}$ & $\begin{array}{l}\text { Obstructive CAD, severe AP (CCS } \\
\text { class II-IV) despite optimal medical } \\
\text { therapy, objective evidence of } \\
\text { myocardial ischemia and LVEF } \\
\geq 25 \% \text {, non-candidates for PCI, pre- } \\
\text { screened pts passing the treadmill } \\
\text { exercise test, echo dobutamine test, } \\
\text { and radionuclide perfusion scan }\end{array}$ \\
\hline Exclusion criteria & $\begin{array}{l}\text { MI within } 3 \text { mos, } \mathrm{PCl} \text { or CABG } \\
\text { within } 7 \text { mos, severe arrhythmias, } \\
\text { decompensated heart failure, severe } \\
\text { valvular heart disease, pacemaker } \\
\text { or other } \mathrm{CS} \text { electrode, mean RAP } \\
\geq 15 \mathrm{mmHg} \text {, pts who had undergone } \\
\text { tricuspid valve replacement or } \\
\text { repair }\end{array}$ & $\begin{array}{l}\text { Ischemia related exclusively to right } \\
\text { coronary artery, presence of a } \\
\text { pacemaker lead in CS, acute } \\
\text { coronary syndrome in }<3 \text { mos, } \\
\text { coronary revascularization in }<6 \\
\text { mos, mean right atrial pressure }>15 \\
\mathrm{mmHg}\end{array}$ & $\begin{array}{l}\text { MI in }<3 \text { mos, } \mathrm{PCI} / \mathrm{CABG}<3 \text { mos, } \\
\text { life-threatening rhythm disorders or } \\
\text { those requiring ICD or pacemaker } \\
\text { (or other } \mathrm{CS} \text { electrode), } \\
\text { decompensated heart failure, severe } \\
\text { valvular heart disease, tricuspid } \\
\text { valve replacement } / \text { repair pts, pts } \\
\text { with mean RAP }>15 \mathrm{mmHg}\end{array}$ \\
\hline Primary outcome measure & $\begin{array}{l}\text { Efficacy: NA } \\
\text { Safety: Absence of procedure- } \\
\text { related SAEs (death, MI, perforation } \\
\text { of CS, CS occlusion), need for } \\
\text { urgent dilation of the Reducer }\end{array}$ & $\begin{array}{l}\text { Efficacy: Change in AP severity } \\
\text { assessed by CCS and SAQ, Six- } \\
\text { Minute Walk Test } \\
\text { Safety: Successful delivery and } \\
\text { deployment of the Reducer in the CS } \\
\text { (assessed by angiogram and/or CT } \\
\text { angiography), AEs and SAEs (death, } \\
\text { MI, cardiac tamponade), clinically } \\
\text { driven revision of an implanted device } \\
\text { (eg due to embolization or } \\
\text { suboptimal implantation position), } \\
\text { life-threatening arrhythmias, } \\
\text { respiratory failure needing invasive } \\
\text { ventilation, access site complications, } \\
\text { CS dissection }\end{array}$ & $\begin{array}{l}\text { Efficacy: Change in AP severity } \\
\text { assessed by CSS class } \\
\text { Safety: NA }\end{array}$ \\
\hline
\end{tabular}


Table 3 (Continued).

\begin{tabular}{|c|c|c|c|}
\hline Authors (Year) & Banai et $\mathrm{al}^{19}(2007)$ & Giannini et $\mathrm{al}^{20}(2018)$ & Konigstein et $\mathrm{al}^{16}(2014)$ \\
\hline Secondary outcome measure & $\begin{array}{l}\text { Successful delivery and deployment } \\
\text { of the Reducer in the CS (assessed } \\
\text { by angiogram and/or CT } \\
\text { angiography) }\end{array}$ & $\begin{array}{l}\text { Exercise stress test, myocardial } \\
\text { scintigraphy with technetium-99, } \\
\text { dobutamine stress test, WMSI }\end{array}$ & NA \\
\hline \multicolumn{4}{|l|}{ Baseline patient characteristics } \\
\hline Mean age, yrs $( \pm S D)$ & 65 (range $50-80$ ) & $69.4(10.7)$ & $71.4(9.8)$ \\
\hline Sex, female:male, $n$ & $3: 12$ & $74: 67$ & $7: 16$ \\
\hline Previous MI, n (\%) & $4(27)$ & $76(54)$ & $19(83)$ \\
\hline Previous CABG, n (\%) & $3(20)$ & $107(76)$ & $17(74)$ \\
\hline Previous PCI, n (\%) & $6(40)$ & $116(82)$ & Unclear $^{d}$ \\
\hline Previous stroke, $\mathbf{n}(\%)$ & NA & $13(9)$ & $4(17)^{\mathrm{e}}$ \\
\hline Previous PAD, n (\%) & NA & $31(22)$ & $5(22)$ \\
\hline Previous pacemaker, n (\%) & NA & $13(9)$ & NA \\
\hline Hypercholesterolemia, n (\%) & NA & NA & NA \\
\hline Diabetes mellitus, n (\%) & I (7) & $63(45)$ & $13(56.5)$ \\
\hline Hypertension, n (\%) & $10(67)$ & II 8 (84) & $18(78)$ \\
\hline Hyperlipidemia, n (\%) & $5(33)$ & $45(32)^{f}$ & $20(87)$ \\
\hline Current/previous smoking, n (\%) & NA & $52(37)$ & $10(43.5)$ \\
\hline \multicolumn{4}{|l|}{ CSS angina class, $\mathbf{n}(\%)$} \\
\hline Class II & I (7) & $19(13)$ & NA \\
\hline Class III & $12(80)$ & $99(70)$ & NA \\
\hline Class IV & $2(13)$ & $23(16)$ & NA \\
\hline LVEF, n (士SD) & NA & Mean $53.0(8.7)$ & NA \\
\hline No. of antianginal medications, $n$ & NA & Mean $2.33 \pm 0.97^{g}$ & NA \\
\hline Follow-up, mos & 6 & $6^{\mathrm{h}}$ & 6 \\
\hline Loss to follow-up, n (\%) & 0 & $2(I)^{i}$ & 3 \\
\hline \multicolumn{4}{|l|}{ Efficacy } \\
\hline $\begin{array}{l}\text { CCS angina score reduction of at } \\
\text { least } 2 \text { classes at follow-up, } n(\%)\end{array}$ & NA & $63(45)^{j}$ & NA \\
\hline $\begin{array}{l}\text { CCS angina score reduction of at } \\
\text { least I class at follow-up, } n(\%)\end{array}$ & NA & $113(8 \mathrm{I})$ & NA \\
\hline $\begin{array}{l}\text { Reduction in CSS class, } \mathbf{n} \\
\text { (baseline/follow-up) }\end{array}$ & Average $1.43(3.07 / I .64) p<0.0001$ & $\begin{array}{l}\text { Mean I.42 }(3.05 \pm 0.53 / 1.63 \pm 0.98) \\
p<0.00 \text { I }\end{array}$ & $\begin{array}{l}\text { Mean } 1.35^{k}(3.35 \pm 0.6 / 2.0 \pm I) \\
p<0.001\end{array}$ \\
\hline $\begin{array}{l}\text { SAQ QoL score improvement, n } \\
\text { of points (baseline/follow-up) }\end{array}$ & 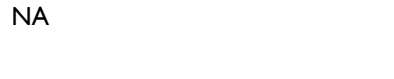 & $\begin{array}{l}25.61(26.6 \pm 16.5 / 52.2 \pm 19.9) \\
p<0.001\end{array}$ & NA \\
\hline $\begin{array}{l}\text { Exercise treadmill stress test, } \\
\text { mean } \mathbf{n} \text { of } \mathrm{min} \text {, (baseline/follow-up) }\end{array}$ & NA & $6: 15 \pm 2.49 / 6: 28 \pm 3.44^{\mathrm{m}} \mathrm{NA}$ & $3: 16 \pm 1.48 / 5: 16 \pm 1.14 p=0.05$ \\
\hline \multicolumn{4}{|l|}{$\begin{array}{l}\text { WMSI improvement, \%, } \\
\text { (baseline/follow-up) }\end{array}$} \\
\hline At rest & NA & $1.34 \pm 0.42 / 1.31 \pm 0.40 p=0.662$ & $1.5 \pm 0.3 / 1.3 \pm 0.4 p=0.34$ \\
\hline At stress & NA & $1.46 \pm 0.40 / I .46 \pm 0.28 p=0.982$ & $1.9 \pm 0.4 / 1.4 \pm 0.4 p=0.046$ \\
\hline $\begin{array}{l}\text { ST-segment depression during } \\
\text { exercise, } \mathrm{n} \text { of } \mathrm{mm} \text { (at mean heart } \\
\text { rate beats } / \mathrm{min} \text { ) (baseline/follow- } \\
\text { up) }\end{array}$ & $2(117) / 1.22(124) p=0.047$ & NA & NA \\
\hline $\begin{array}{l}\text { Antianginal medication intake, } \\
\text { median n (baseline/follow-up) }\end{array}$ & NA & NA & NA \\
\hline
\end{tabular}

(Continued) 
Table 3 (Continued).

\begin{tabular}{|c|c|c|c|}
\hline Authors (Year) & Banai et al ${ }^{19}(2007)$ & Giannini et $\mathrm{al}^{20}(20 \mid 8)$ & Konigstein et $\mathrm{al}^{16}(20 \mid 4)$ \\
\hline \multicolumn{4}{|l|}{ Safety } \\
\hline SADEs, n (\%) & $0(0)$ & $14(10)$ & $5(22)$ \\
\hline Death, n (\%) & NA & $14(10)^{n}$ & I $(4)^{\circ}$ \\
\hline MI, n (\%) & NA & NA & NA \\
\hline Stable angina, $n(\%)$ & NA & NA & $4(17)^{\mathrm{P}}$ \\
\hline Crohn's disease flare, n (\%) & NA & NA & NA \\
\hline Unstable angina, $\mathrm{n}(\%)$ & NA & NA & NA \\
\hline Epigastric pain, n (\%) & NA & NA & NA \\
\hline Atypical chest pain, n (\%) & NA & NA & NA \\
\hline Acute coronary syndrome, n (\%) & NA & NA & NA \\
\hline Arrhythmia, n (\%) & NA & NA & NA \\
\hline Multi-system failure/death, n (\%) & NA & NA & NA \\
\hline Pulmonary edema,n (\%) & NA & NA & NA \\
\hline COPD, n (\%) & NA & NA & NA \\
\hline Cough, n (\%) & NA & NA & NA \\
\hline Decompensated heart failure, $\mathrm{n}(\%)$ & NA & NA & NA \\
\hline Gastrointestinal bleeding, n (\%) & NA & NA & NA \\
\hline Injury, n (\%) & NA & NA & NA \\
\hline CAD progression, $\mathrm{n}(\%)$ & NA & NA & NA \\
\hline $\begin{array}{l}\text { Bleeding events associated with } \\
\text { dual antiplatelet therapy, } n(\%)\end{array}$ & NA & NA & NA \\
\hline \multicolumn{4}{|l|}{ ADEs (at least I ADE in $n$ of pts } \\
\hline Hospitalization, n (\%) & NA & $23(17)^{9}$ & NA \\
\hline Coronary angiogram, $\mathrm{n}(\%)$ & NA & $26(19)^{r}$ & NA \\
\hline Revascularization, n (\%) & NA & $15(11)^{5}$ & NA \\
\hline Device migration, $\mathrm{n}(\%)$ & NA & NA & NA \\
\hline
\end{tabular}

Notes: an study limitations, it is stated that the present study is retrospective, while in the methods section, it is stated that the study is prospective; ${ }^{\mathrm{C}} \mathrm{Q}$-L measure (CCS score) reported on I4/I5 pts. ST-segment depression during exercise stress test reported in 9/15 pts; ' Failure to implant CSRS in 2 pts owing to unsuitable CS anatomy, and I pt lost to follow-up; ${ }^{\mathrm{d}} \mathrm{Number}$ of pts having undergone PCl us not stated. It is only stated that mean number of PCls was $4.8 \pm 4.2$; ${ }^{\mathrm{e}} \mathrm{Stroke}$ or transient ischemic event; ${ }^{\mathrm{f}} \mathrm{Dyslipidemia;}{ }^{\mathrm{g}}$ Mean number of antianginal medications, including anti-ischemic and acetylsalicylic acid therapy; ${ }^{\text {h}}$ Follow-up was performed either by telephone or at a face-to-face clinic visit; 'Lost to follow-up due to failed CSRS implantation; 'Of which 20 pts (14\%) demonstrated reduction of 3 CCS classes; 'Results on 20 pts; 'Other SAQ score results were: physical limitation scores improved from $43.9 \pm 17.6$ to $62.2 \pm 20.7$ points ( $p<0.001$ ); angina stability scores from $36.9 \pm 20.4$ to $66.6 \pm 27.0$ points ( $p<0.001$ ); angina frequency scores from $45.6 \pm 22$.I to $66.7 \pm 20.8$ points $(p<0.00 \mathrm{I})$; treatment satisfaction scores from $51.9 \pm 22.0$ to $68.4 \pm 17.6$ points $(p<0.00 \mathrm{I})$; ${ }^{\mathrm{m}}$ Results on $5 \mathrm{I}$ pts; ${ }^{\mathrm{n}} 2$ deaths due to fatal Ml, I due to advanced heart failure, I due to refractory angina leading to anorexia and decubitus. The remaining 10 deaths are claimed not to be of cardiovascular origin; ${ }^{\circ} \mathrm{I} \mathrm{pt}$ died $\mathrm{I}$ year after the procedure. The implantation of CSRS was not successful in this pt and this pt died of heart failure; PIt is unclear whether the angina was stable or unstable. 2 of these pts we treated by PCl, I by CABG, and I pharmacologically; ${ }^{9}$ Due to recurrent angina; ${ }^{7} 7$ pts underwent 2 angiograms, I pt 3 , and another 5 ; ${ }^{5}$ Further revascularizations due to de novo lesions; ${ }^{t} \mathrm{No}$ information is stated concerning AEs; however, based on results from the rest of the studies, it is assumed that $A E s$ occurred, but were not reported.

Abbreviations: ADE, adverse device effect; AP, angina pectoris; CABG, coronary artery bypass grafting; CAD, coronary artery disease; CCS, Canadian Cardiovascular Society; CHF, congestive heart failure; CMR, cardiac magnetic resonance; CS, coronary sinus; CSRS, coronary sinus reducing stent; COPD, chronic obstructive pulmonary disease; CRT, cardiac resynchronization therapy; CS, coronary sinus; ECG, electrocardiogram; hrs, hours; ICD, implantable cardioverter defibrillator; LVEF, left ventricular ejection fraction; MI, myocardial infarction; mos, months; MRI, magnetic resonance imaging; $n$, number; NA, not available; $p$, p-value; PAD, peripheral artery disease; PCI, percutaneous coronary intervention; pts, patients; QoL, quality of life; RAP, right atrial pressure; SADE, serious adverse device effect; SAQ, Seattle Angina Questionnaire; SD, standard deviation; TAVR, transcatheter aortic valve replacement; WMSI, Wall Motion Score Index; yr, year.

SADEs occurred in no more than two patients in the $\mathrm{IG}$ or $\mathrm{CG}$, with the exception of the following: atypical chest pain $(\mathrm{IG}=1$, $\mathrm{CG}=6)$, unstable angina $(\mathrm{IG}=1, \mathrm{CG}=4)$, and stable angina $(\mathrm{IG}=1, \mathrm{CG}=5)$. With respect to ADEs, they were reported in 32 patients $(64 \%)$ in the IG and $37(69 \%)$ in the CG.

\section{Prospective Observational Non-Comparative Studies}

All of the observational evidence reported SADEs and ADEs at 4-6 months of follow-up, except for one study with the longest follow-up (which reported results at 24 months). ${ }^{15}$ This was also the study with the highest number of SADEs $(30 \%)$.

While two observational studies reported no SADEs, ${ }^{14,19}$ the remaining four studies reported 14 (10\%), five (22\%), six (13\%), and 15 patients (30\%) suffering from SADEs, respectively. ${ }^{15-18}$ The SADE of death occurred in 14 patients $(10 \%),{ }^{18}$ in one patient $(4 \%),{ }^{16}$ in three patients $(6 \%),{ }^{17}$ and in five patients $(10 \%) \cdot{ }^{15} \mathrm{MI}$ occurred in one study ${ }^{15}$ in three 
Table 4 CSRS: Results from Observational Studies (Part 2)

\begin{tabular}{|c|c|c|c|}
\hline Authors (Year) & Konigstein et $\mathrm{al}^{17}(2018)$ & Ponticelli et al ${ }^{15}$ (2019) & 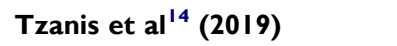 \\
\hline Country & Israel & Italy & Italy \\
\hline Sponsor & Neovasc Inc. & Neovasc Inc. & Neovasc Inc. \\
\hline Study design & $\begin{array}{l}\text { Single-center, open-label, } \\
\text { prospective registry }\end{array}$ & $\begin{array}{l}\text { Single-center, prospective case } \\
\text { series }\end{array}$ & $\begin{array}{l}\text { Single-center, prospective case } \\
\text { series }\end{array}$ \\
\hline Conducted in & $08 / 2011-11 / 2017$ & $03 / 2015-08 / 2016$ & NA \\
\hline Indication & $\begin{array}{l}\text { Refractory AP despite standard } \\
\text { medical therapy (pts with CAD, } \\
\text { reversible ischemia, no } \\
\text { candidates for revascularization) }\end{array}$ & $\begin{array}{l}\text { Refractory AP despite standard } \\
\text { medical therapy (pts with CAD, } \\
\text { reversible ischemia, no candidates } \\
\text { for revascularization) }\end{array}$ & $\begin{array}{l}\text { Refractory AP despite standard } \\
\text { medical therapy }\end{array}$ \\
\hline Intervention & $\begin{array}{l}\text { Coronary-sinus reducing stent } \\
\text { (Reducer) }\end{array}$ & $\begin{array}{l}\text { Coronary-sinus reducing stent } \\
\text { (Reducer) }\end{array}$ & $\begin{array}{l}\text { Coronary-sinus reducing stent } \\
\text { (Reducer) }\end{array}$ \\
\hline Comparator & None & None & None \\
\hline Number of pts & $48^{\mathrm{a}}$ & 50 & 19 \\
\hline Inclusion criteria & $\begin{array}{l}\text { Severe AP (CCS class III or IV) } \\
\text { despite optimal medical therapy, } \\
\text { objective evidence of myocardial } \\
\text { ischemia of left coronary arteries } \\
\text { territory by perfusion scan and/ } \\
\text { or by dobutamine ECG, LVEF } \\
\geq 30 \% \text {, non-candidates for surgical } \\
\mathrm{PCI}\end{array}$ & $\begin{array}{l}\text { Severe AP (CCS class II-IV) } \\
\text { despite optimal medical therapy, } \\
\text { objective evidence of myocardial } \\
\text { ischemia of left coronary arteries } \\
\text { territory by perfusion scan and/ } \\
\text { or by dobutamine ECG or stress } \\
\text { perfusion cardiac MRI, CAD not } \\
\text { amenable to PCI/CABG due to } \\
\text { unsuitable coronary anatomy, } \\
\text { diffuse disease, or absence of } \\
\text { satisfactory distal graft } \\
\text { anastomosis sites }\end{array}$ & $\begin{array}{l}\text { Severe AP (CCS class II-IV) } \\
\text { despite optimal medical therapy, } \\
\text { objective evidence of inducible } \\
\text { myocardial ischemia involving at } \\
\text { least one myocardial segment at } \\
\text { dipyridamole stress cardiac MRI, } \\
\text { coronary artery disease not } \\
\text { amenable to further } \\
\text { revascularization with PCI/CABG }\end{array}$ \\
\hline Exclusion criteria & $\begin{array}{l}\mathrm{MI}, \mathrm{PCl}, \mathrm{CABG} \text { in }<3 \text { mos, life- } \\
\text { threatening rhythm disorders, } \\
\text { decompensated heart failure, } \\
\text { severe valvular heart disease, } \\
\text { LVEF }<30 \% \text { who may require } \\
\text { CRT, mean RAP }>15 \mathrm{mmHg}\end{array}$ & $\begin{array}{l}\text { Ischemia related exclusively to } \\
\text { right coronary artery, presence of } \\
\text { a foreign body in the CS (eg a left } \\
\text { ventricular pacemaker wire for } \\
\text { cardiac resynchronization } \\
\text { therapy), acute coronary } \\
\text { syndrome in }<3 \text { mos, coronary } \\
\text { revascularization in }<6 \text { mos, mean } \\
\text { RAP }>15 \mathrm{mmHg}\end{array}$ & $\begin{array}{l}\text { Acute coronary syndrome in }<3 \\
\text { mos, coronary revascularization } \\
\text { in }<6 \text { months, mean RAP }>15 \\
\text { mmHg and } \mathrm{CMR} \text { or dipyridamole } \\
\text { contraindications }\end{array}$ \\
\hline Primary outcome measure & $\begin{array}{l}\text { Efficacy: Change in AP severity } \\
\text { assessed by CSS class, SAQ, } \\
\text { treadmill stress test, echo } \\
\text { dobutamine } \\
\text { Safety: NA }\end{array}$ & $\begin{array}{l}\text { Efficacy: Change in AP severity } \\
\text { assessed by CSS class, SAQ, } \\
\text { improvement in exercise } \\
\text { tolerance assessed using the Six- } \\
\text { Minute Walk Test, and reduction } \\
\text { in pharmacological antianginal } \\
\text { therapy } \\
\text { Safety: procedural success and } \\
\text { absence of device-related AEs }\end{array}$ & $\begin{array}{l}\text { Efficacy: CCS class improvement, } \\
\text { Six-Minute Walk Test, and } \\
\text { reduction in pharmacological } \\
\text { antianginal therapy } \\
\text { Safety: SAEs and AEs }\end{array}$ \\
\hline Secondary outcome measure & NA & NA & NA \\
\hline
\end{tabular}

(Continued) 
Table 4 (Continued).

\begin{tabular}{|c|c|c|c|}
\hline Authors (Year) & Konigstein et $\mathrm{al}^{17}(2018)$ & Ponticelli et al $^{15}(2019)$ & 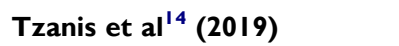 \\
\hline \multicolumn{4}{|l|}{ Baseline patient characteristics } \\
\hline Mean age, yrs ( $\pm S D)$ & $66.8(8.9)$ & $68(9)$ & 66 (IQR 56-77) \\
\hline Sex, female:male, $n$ & $8: 40$ & $9: 41$ & $1: 18$ \\
\hline Previous MI, n (\%) & $25(52)$ & $33(66)^{c}$ & $18(95)$ \\
\hline Previous CABG, n (\%) & $39(8 \mathrm{I})$ & $28(56)^{d}$ & II (58) \\
\hline Previous PCI, n (\%) & $48(100)$ & $38(76)$ & NA \\
\hline Previous stroke, n (\%) & $7(\mid 4.5)$ & NA & NA \\
\hline Previous PAD, n (\%) & $10(2 \mathrm{I})$ & NA & NA \\
\hline Previous pacemaker, n (\%) & NA & NA & NA \\
\hline Hypercholesterolemia, n (\%) & $48(100)$ & NA & NA \\
\hline Diabetes mellitus, n (\%) & $31(64)$ & $22(44)$ & NA \\
\hline Hypertension, n (\%) & $4 \mid(85)$ & $43(86)$ & NA \\
\hline Hyperlipidemia, n (\%) & NA & $45(90)^{\mathrm{e}}$ & NA \\
\hline $\begin{array}{l}\text { Current/previous smoking, n } \\
\text { (\%) }\end{array}$ & $27(56)$ & $32(64)$ & NA \\
\hline \multicolumn{4}{|l|}{ CSS angina class, $n$ (\%) } \\
\hline Class II & I (2) & $7(14)$ & $N A^{f}$ \\
\hline Class III & $19(49)$ & $36(72)$ & NA \\
\hline Class IV & $19(49)$ & $7(14)$ & NA \\
\hline LVEF, n (士SD) & NA & Mean $52(\mathrm{II})$ & Median 6I (IQR 47-7I) \\
\hline No. of antianginal medications, $n$ & $N A^{g}$ & Median 3 (range I-5) ${ }^{\mathrm{h}}$ & Median 3 (range $1-5)^{i}$ \\
\hline Follow-up, mos & 6 & 24 & 4 \\
\hline Loss to follow-up, $n$ (\%) & $3^{\mathrm{j}}$ & $8^{k}$ & 0 \\
\hline \multicolumn{4}{|l|}{ Efficacy } \\
\hline $\begin{array}{l}\text { CCS angina score reduction of at } \\
\text { least } 2 \text { classes at follow-up, } n(\%)\end{array}$ & $19(40)$ & NA & $7(37)$ \\
\hline $\begin{array}{l}\text { CCS angina score reduction of at } \\
\text { least I class at follow-up, } n \text { (\%) }\end{array}$ & $33(69)$ & NA & $16(84)$ \\
\hline Reduction in CSS class, $\mathbf{n}$ & Mean I. $4^{\prime}(3.4 \pm 0.5 / 2.0 \pm 1)$ & Mean I.26 (I.74 $\pm 0.86 / 3.0 \pm 0.5 I)$ & Median 2 (3 IQR 3-3/I (IQR I-2) \\
\hline $\begin{array}{l}\text { (baseline/tollow-up) } \\
\text { SAQ QoL score improvement, n } \\
\text { of points (baseline/follow-up) }\end{array}$ & $\begin{array}{l}p<0.001 \\
p<0.001\end{array}$ & $(58.76 \pm|8.08 / 25.67 \pm| 2.35)$ & $\mathrm{NA}$ \\
\hline $\begin{array}{l}\text { Exercise treadmill stress test, } \\
\text { mean } \mathbf{n} \text { of } \mathbf{m i n} \text { (baseline/follow- } \\
\text { up) }\end{array}$ & $3: 43 \pm 1: 30 / 4: 35 \pm 2: 18 p=0.025$ & NA & $\begin{array}{l}300(\text { IQR 240-382)/420 (IQR } \\
353-515)^{\mathrm{n}} p=0.002\end{array}$ \\
\hline \multicolumn{4}{|l|}{$\begin{array}{l}\text { WMSI improvement, \% } \\
\text { (baseline/follow-up) }\end{array}$} \\
\hline At rest & $1.46 \pm 0.42 / 1.43 \pm 0.44 p=0.89$ & NA & NA \\
\hline At stress & $1.58 \pm 0.37 / 1.37 \pm 0.36 p=0.004$ & NA & NA \\
\hline $\begin{array}{l}\text { ST-segment depression during } \\
\text { exercise, } \mathrm{n} \text { of } \mathrm{mm} \text { (at mean } \\
\text { heart rate beats/min) (baseline/ } \\
\text { follow-up) }\end{array}$ & $299.9 \pm 97.9 / 352.9 \pm 75.3 p=0.002$ & NA & NA \\
\hline $\begin{array}{l}\text { Antianginal medication intake, } \\
\text { median n (baseline/follow-up) }\end{array}$ & NA & $3(\mathrm{IQR} 2-4) / 3(\mathrm{IQR} 2-4) p=0.101$ & $3($ IQR 2-3)/3 (IQR 2-3) $p=0.296$ \\
\hline
\end{tabular}

(Continued) 
Table 4 (Continued).

\begin{tabular}{|c|c|c|c|}
\hline Authors (Year) & Konigstein et $\mathrm{al}^{17}(2018)$ & Ponticelli et al $\left.\right|^{15}(2019)$ & Tzanis et al ${ }^{14}(2019)$ \\
\hline \multicolumn{4}{|l|}{ Safety } \\
\hline SADEs, n (\%) & $6(13)$ & $15(30)$ & 0 \\
\hline Death, n (\%) & $3(6)^{\circ}$ & $5(10)^{\mathrm{P}}$ & NA \\
\hline MI, n (\%) & NA & $3(6)$ & NA \\
\hline Stable angina, $\mathrm{n}(\%)$ & $2(4)$ & NA & NA \\
\hline Crohn's disease flare, $\mathrm{n}(\%)$ & NA & NA & NA \\
\hline Unstable angina, $\mathrm{n}(\%)$ & I (2) & NA & NA \\
\hline Epigastric pain, n (\%) & NA & NA & NA \\
\hline Atypical chest pain, n (\%) & NA & NA & NA \\
\hline Acute coronary syndrome, $\mathrm{n}(\%)$ & NA & NA & NA \\
\hline Arrhythmia, n (\%) & NA & NA & NA \\
\hline Multi-system failure/death, $\mathrm{n}(\%)$ & NA & NA & NA \\
\hline Pulmonary edema,n (\%) & NA & NA & NA \\
\hline COPD, n (\%) & NA & NA & NA \\
\hline Cough, n (\%) & NA & NA & NA \\
\hline Decompensated heart failure, $n(\%)$ & NA & NA & NA \\
\hline Gastrointestinal bleeding, n (\%) & NA & NA & NA \\
\hline Injury, n (\%) & NA & NA & NA \\
\hline CAD progression, $\mathrm{n}(\%)$ & NA & $7(14)$ & NA \\
\hline $\begin{array}{l}\text { Bleeding events associated with } \\
\text { dual antiplatelet therapy, n (\%) }\end{array}$ & NA & NA & NA \\
\hline $\begin{array}{l}\text { ADEs (at least I ADE in } n \text { of pts } \\
\text { (\%)) }\end{array}$ & $4(8)$ & $13(26)$ & 0 \\
\hline Hospitalization, n (\%) & NA & NA & NA \\
\hline Coronary angiogram, n (\%) & NA & $13(26)^{9}$ & NA \\
\hline Revascularization, n (\%) & $3(6)$ & NA & 0 \\
\hline Device migration, $\mathrm{n}(\%)$ & I (2) & NA & $0^{r}$ \\
\hline
\end{tabular}

Notes: ${ }^{\mathrm{a} F a i l u r e}$ to implant CSRS in 2 pts owing to unsuitable CS anatomy; Inclusion and exclusion criteria come from the I2-mo publication from Giannini et al (20I8); ${ }^{17}$ All baseline criteria reported from the 12-mo publication from Giannini et al (2018); ${ }^{17} \mathrm{~d} C A B G$ and PCl one; ${ }^{e}$ Dyslipidemia reported; ${ }^{\mathrm{f}}$ Baseline information only on pooled CSS class: 3 (IQR 3-3); ${ }^{g}$ Antianginal medications include beta-blockers, calcium-channel blockers, ACE/ARB inhibitors, nitrates, diuretics, aspirin, clopidogrel, warfarin, statins, ivabradine; ${ }^{h}$ Antianginal medications include beta-blockers, calcium-channel antagonists, long-acting nitrates, ivabradine, ranolazine; 'Antianginal medications include beta-blockers, calciumchannel antagonists, nitrates, ranolazine, ivabradine, aspirin, clopidogrel; 3 lost to follow-up and 4 other pts not yet completed the 6-mo evaluation and hence not part of the analysis; ${ }^{\mathrm{k}} 5$ pts died and 3 were not reachable by telephone calls or emails; 'Results on 39 pts; ${ }^{\mathrm{m}}$ Results on 23 pts; 'Results on Six-Minute Walk Test; ${ }^{\circ} \mathrm{None}$ is claimed to be related to CSRS. I death due to gradual general physical deterioration, I sudden death without explanation for its cause, and I patient diagnosed with severe aortic stenosis underwent TAVR and died after the procedure; ${ }^{2} 2$ pts died during the first 12 mos due to an ischemic stroke and a urological malignancy, and 3 pts died because of out-of-hospital cardiac arrest, pulmonary malignancy, and nosocomial infection during a hospitalization for heart failure; ${ }^{9}$ Angiography; ${ }^{\mathrm{r}}$ Results on device embolization.

Abbreviations: ADE, adverse device effect; AP, angina pectoris; CABG, coronary artery bypass grafting; CAD, coronary artery disease; CCS, Canadian Cardiovascular Society; CHF, congestive heart failure; CMR, cardiac magnetic resonance; COPD, chronic obstructive pulmonary disease; CRT, cardiac resynchronization therapy; CS, coronary sinus; CSRS, coronary sinus reducing stent; ECG, electrocardiogram; hrs, hours; ICD, implantable cardioverter defibrillator; LVEF, left ventricular ejection fraction; MI, myocardial infarction; mos, months; MRI, magnetic resonance imaging; n, number; NA, not available; $p$, p-value; PAD, peripheral artery disease; PCI, percutaneous coronary intervention; pts, patients; QoL, quality of life; RAP, right atrial pressure; SADE, serious adverse device effect; SAQ, Seattle Angina Questionnaire; SD, standard deviation; TAVR, transcatheter aortic valve replacement; WMSI, Wall Motion Score Index; yr, year.

patients $(6 \%)$, and stable angina in two studies ${ }^{16,17}$ in four $(17 \%)$ and two patients (4\%), respectively. Coronary artery disease $(\mathrm{CAD})$ progression further occurred in seven patients $(14 \%)^{15}$ and unstable angina in one patient $(2 \%) .{ }^{17}$ With respect to ADEs, those reported were hospitalization, coronary angiogram, revascularization, and device migration. They were not reported in two studies ${ }^{16,19}$ and were reported to be none in another study. ${ }^{14}$ Furthermore, they were reported to occur in 64 patients $(45 \%),{ }^{18}$ four patients
$(8 \%),{ }^{17}$ and 13 patients $(26 \%) .{ }^{15}$ See Tables 2,3 , and 4 for further details.

\section{RoB and Quality of Evidence}

The RoB of the RCT was rated to be low, the RoB of observational studies was rated to range from low $14,15,17,19$ to moderate ${ }^{16,18}$ (Tables 5 and 6), and the strength of evidence assessed by GRADE was rated moderate (Table 7). 
Table 5 Risk of Bias - Study Level (RCT) $)^{5}$

\begin{tabular}{|c|c|c|c|c|c|c|c|}
\hline \multirow[t]{2}{*}{ Trial } & \multirow{2}{*}{$\begin{array}{l}\text { Adequate } \\
\text { Generation of } \\
\text { Randomization } \\
\text { Sequence }\end{array}$} & \multirow{2}{*}{$\begin{array}{l}\text { Adequate } \\
\text { Allocation } \\
\text { Concealment }\end{array}$} & \multicolumn{2}{|l|}{ Blinding } & \multirow{2}{*}{$\begin{array}{l}\text { Selective } \\
\text { Outcome } \\
\text { Reporting } \\
\text { Unlikely }\end{array}$} & \multirow{2}{*}{$\begin{array}{l}\text { No Other Aspects } \\
\text { Which Increase the } \\
\text { Risk of Bias }\end{array}$} & \multirow{2}{*}{$\begin{array}{l}\text { Risk of } \\
\text { Bias - } \\
\text { Study } \\
\text { Level }\end{array}$} \\
\hline & & & Patient & $\begin{array}{l}\text { Treating } \\
\text { Physician }\end{array}$ & & & \\
\hline $\operatorname{COSIRA}^{13}$ & Yes & Yes & Yes & No & No & Yes & Low \\
\hline
\end{tabular}

\section{Discussion}

For the analysis of clinical effectiveness, one RCT with 104 patients was included, ${ }^{13}$ indicating a statistically significant improvement in two crucial outcomes (CCS angina score improvement by one/two classes and SAQ QoL score). The third crucial outcome (SAQ treatment satisfaction) did not improve in a statistically significant way $(p=0.981)$, neither did the more objective outcomes (total exercise duration or WMSI). For the analysis of safety, additional six prospective observational studies with 296 patients were included as well. In total, 348 patients received the CSRS therapy. Based on the RCT data, there were fewer SADEs associated with CSRS compared to the $\mathrm{CG}$ and the only case of death occurred in the CG. With respect to observational evidence, there remains a point of concern as the SADEs range from none ${ }^{14,19}$ to $30 \%{ }^{15}$ (with the highest number of SADEs occurring in the study with the longest follow-up). Furthermore, $8 \%$ of patients from observational studies died, while $5 \%$ of deaths were explicitly claimed not to be related to the CSRS. ${ }^{15-18}$

In our systematic search, we found only one other HTA on the CSRS therapy, which, however, included both prospective and retrospective evidence and arrived at a positive conclusion toward the CSRS therapy. ${ }^{7}$ Our HTA is solely based on prospective evidence and our conclusion is more reserved. Also, even though CSRS therapy seems to be a promising treatment for refractory AP patients (with respect to two crucial outcomes and a relatively positive safety profile), the internal and external validity of the studies in the present evidence base is uncertain.

\section{Internal Validity}

Regardless of the relatively positive assessment of the evidence quality (low to moderate RoB and moderate strength of evidence), the following issues need to be considered when interpreting the findings on both clinical effectiveness and safety.

\section{Clinical Effectiveness}

When interpreting the clinical effectiveness findings, issues with inappropriate inclusion criteria, mechanism of action, placebo effect, sample size, and the randomization procedure should be considered.

First, the main point of concern is the discrepancy between the inclusion criteria in all the studies included in the analysis and the definition of refractory AP (as defined by the ESC $^{5}$ ). The ESC defines refractory AP as longlasting symptoms (for $\geq 3$ months) due to established reversible ischemia in the presence of obstructive CAD, which cannot be controlled by escalating medical therapy with the use of second- and third-line pharmacological agents, bypass grafting, or stenting, including PCI of chronic total coronary occlusion. ${ }^{5}$ Contrary to the definition, none of the studies included patients with symptoms lasting for more or equal to 3 months and, furthermore, while three studies did not report on previous pharmacological therapy, ${ }^{16,17,19}$ patients with one to five courses of pharmacological treatment were included in two studies, ${ }^{14,15} 1.34-3.3$ courses in one study, ${ }^{18}$ and in the RCT, $25 \%$ of patients had zero or one course of medication and $31 \%$ had at least three courses. ${ }^{13}$

Second, there is a lack of clarity behind the mechanism of action of the CSRS. The main hypothesis is that the CSRS alleviates symptoms by improving perfusion in ischemic myocardial territories, but no study has evaluated the effect of the CSRS on myocardial perfusion to demonstrate its mechanism of action. ${ }^{20}$ One of the potential issues is related to the claimed beneficial hemodynamic changes, which are at odds with one of the principles of use of intermittent and pressure-controlled increase in coronary sinus pressure - a release of obstruction ${ }^{22}$ resulting in rapid reduction of coronary sinus pressure after the prolongedplateau phase, which may induce a sort of aspirating effect on fluids and toxic metabolites that have accumulated in the ischemic segment. ${ }^{23}$ It is further known that coronary sinus flow at rest and hyperemic states are in agreement with myocardial blood flow values, and reduced coronary flow reserve measured at the coronary sinus level may have an association with adverse outcome. $^{24}$ 
Table 6 Risk of Bias - Study Level (Case Series) ${ }^{21}$

\begin{tabular}{|c|c|c|c|c|c|c|}
\hline (Year)Authors & $\begin{array}{l}\text { Banai et } \\
\text { al } \\
(2007)^{19}\end{array}$ & $\begin{array}{l}\text { Giannini } \\
\text { et al } \\
(2018)^{20}\end{array}$ & $\begin{array}{l}\text { Konigstein } \\
\text { et al } \\
(2014)^{16}\end{array}$ & $\begin{array}{l}\text { Konigstein } \\
\text { et al } \\
(2018)^{17}\end{array}$ & $\begin{array}{l}\text { Ponticelli } \\
\text { et al } \\
(2019)^{15}\end{array}$ & $\begin{array}{l}\text { Tzanis et } \\
\text { al } \\
(2019)^{14}\end{array}$ \\
\hline \multicolumn{7}{|l|}{ Study objective } \\
\hline $\begin{array}{l}\text { I. Was the hypothesis/aim/objective of the study } \\
\text { clearly stated? }\end{array}$ & Yes & Yes & No & Yes & Yes & Yes \\
\hline \multicolumn{7}{|l|}{ Study design } \\
\hline $\begin{array}{l}\text { 2. Was the study conducted prospectively? } \\
\text { 3. Were the cases collected in more than one center? } \\
\text { 4. Were patients recruited consecutively? }\end{array}$ & $\begin{array}{l}\text { Yes } \\
\text { Yes } \\
\text { No }\end{array}$ & $\begin{array}{l}\text { Unclear }^{\mathrm{a}} \\
\text { Yes } \\
\text { Yes }\end{array}$ & $\begin{array}{l}\text { Unclear }^{b} \\
\text { Yes } \\
\text { No }\end{array}$ & $\begin{array}{l}\text { Yes } \\
\text { No } \\
\text { Yes }\end{array}$ & $\begin{array}{l}\text { Yes } \\
\text { No } \\
\text { Yes }\end{array}$ & $\begin{array}{l}\text { Yes } \\
\text { No } \\
\text { No }\end{array}$ \\
\hline \multicolumn{7}{|l|}{ Study population } \\
\hline $\begin{array}{l}\text { 5. Were the characteristics of the participants } \\
\text { included in the study described? } \\
\text { 6. Were the eligibility criteria (inclusion and exclusion } \\
\text { criteria) for entry into the study clearly stated? } \\
\text { 7. Did participants enter the study at similar point in } \\
\text { the disease? }\end{array}$ & $\begin{array}{l}\text { Yes } \\
\text { Yes } \\
\text { Yes }\end{array}$ & $\begin{array}{l}\text { Yes } \\
\text { Yes } \\
\text { Yes }\end{array}$ & $\begin{array}{l}\text { Yes }^{c} \\
\text { Yes } \\
\text { Yes }\end{array}$ & $\begin{array}{l}\text { Yes } \\
\text { Yes } \\
\text { Yes }\end{array}$ & $\begin{array}{l}\text { Yes } \\
\text { Yes } \\
\text { Yes }\end{array}$ & $\begin{array}{l}\text { Yes } \\
\text { Yes } \\
\text { Unclear }^{\text {d }}\end{array}$ \\
\hline \multicolumn{7}{|l|}{ Intervention and co-intervention } \\
\hline $\begin{array}{l}\text { 8. Was the intervention clearly described? } \\
\text { 9. Were additional interventions (co-interventions) } \\
\text { clearly described? }\end{array}$ & $\begin{array}{l}\text { Yes } \\
\text { Yes }\end{array}$ & $\begin{array}{l}\text { Partiale } \\
\text { Yes }\end{array}$ & $\begin{array}{l}\text { Yes } \\
\text { Yes }\end{array}$ & $\begin{array}{l}\text { Yes } \\
\text { Yes }\end{array}$ & $\begin{array}{l}\text { Yes } \\
\text { Yes }\end{array}$ & $\begin{array}{l}\text { Yes } \\
\text { Yes }\end{array}$ \\
\hline \multicolumn{7}{|l|}{ Outcome measure } \\
\hline $\begin{array}{l}\text { 10. Were relevant outcome measures established a } \\
\text { priori? } \\
\text { II. Were outcome assessors blinded to the } \\
\text { intervention that patients received? } \\
\text { 12. Were the relevant outcomes measured using } \\
\text { appropriate objective/subjective methods? } \\
\text { 13. Were the relevant outcomes measured before } \\
\text { and after intervention? }\end{array}$ & $\begin{array}{l}\text { Yes } \\
\text { No } \\
\text { Yes } \\
\text { Yes }\end{array}$ & $\begin{array}{l}\text { Yes } \\
\text { No } \\
\text { Yes } \\
\text { Yes }\end{array}$ & $\begin{array}{l}\text { Partialf } \\
\text { No } \\
\text { Yes } \\
\text { Yes }\end{array}$ & $\begin{array}{l}\text { Yes } \\
\text { No } \\
\text { Yes } \\
\text { Yes }\end{array}$ & $\begin{array}{l}\text { Yes } \\
\text { No } \\
\text { Yes } \\
\text { Yes }\end{array}$ & $\begin{array}{l}\text { Yes } \\
\text { No } \\
\text { Yes } \\
\text { Yes }\end{array}$ \\
\hline \multicolumn{7}{|l|}{ Statistical analysis } \\
\hline $\begin{array}{l}\text { 14. Were the statistical tests used to assess the } \\
\text { relevant outcomes appropriate? }\end{array}$ & Yes & Yes & Yes & Yes & Yes & Yes \\
\hline \multicolumn{7}{|l|}{ Results and conclusions } \\
\hline $\begin{array}{l}\text { 15. Was follow-up long enough for important events } \\
\text { and outcomes to occur? } \\
\text { 16. Was the loss to follow-up reported? } \\
\text { 17. Did the study provide estimates of random } \\
\text { variability in the data analysis of relevant outcomes? } \\
\text { 18. Were adverse events reported? } \\
\text { 19. Were the conclusions of the study supported by } \\
\text { results? }\end{array}$ & $\begin{array}{l}\text { Yes } \\
\text { Yes } \\
\text { No } \\
\text { Partial' } \\
\text { Yes }\end{array}$ & $\begin{array}{l}\text { Yes } \\
\text { Yes } \\
\text { Yes } \\
\text { Yes } \\
\text { No' }\end{array}$ & $\begin{array}{l}\text { Yes } \\
\text { Yes } \\
\text { Yes } \\
\text { Partial' } \\
\text { Yes }\end{array}$ & $\begin{array}{l}\text { Yes } \\
\text { Yes } \\
\text { Yes } \\
\text { Yes } \\
\text { No' }\end{array}$ & $\begin{array}{l}\text { Yes } \\
\text { Yes } \\
\text { Yes } \\
\text { Yes } \\
\text { No' }\end{array}$ & $\begin{array}{l}\text { Unclear }^{\mathrm{h}} \\
\text { Yes } \\
\text { Yes } \\
\text { Yes } \\
\mathrm{No}^{\mathrm{j}}\end{array}$ \\
\hline
\end{tabular}

(Continued)

$272 \quad \begin{aligned} & \text { submit your manuscript / wnvwdovepresscom } \\ & \text { Doverpess }\end{aligned} \quad$ Medical Devices: Evidence and Research 2020:13 
Table 6 (Continued).

\begin{tabular}{|c|c|c|c|c|c|c|}
\hline (Year)Authors & $\begin{array}{l}\text { Banai et } \\
\text { al } \\
(2007)^{19}\end{array}$ & $\begin{array}{l}\text { Giannini } \\
\text { et al } \\
(2018)^{20}\end{array}$ & $\begin{array}{l}\text { Konigstein } \\
\text { et al } \\
(2014)^{16}\end{array}$ & $\begin{array}{l}\text { Konigstein } \\
\text { et al } \\
(2018)^{17}\end{array}$ & $\begin{array}{l}\text { Ponticelli } \\
\text { et al } \\
(2019)^{15}\end{array}$ & $\begin{array}{l}\text { Tzanis et } \\
\text { al } \\
(2019)^{14}\end{array}$ \\
\hline \multicolumn{7}{|l|}{ Competing interest and source of support } \\
\hline $\begin{array}{l}\text { 20. Were both competing interest and source of } \\
\text { support for the study reported? }\end{array}$ & Partial $^{k}$ & Partial $^{k}$ & Partial $^{k}$ & Partial $^{k}$ & Partial $^{k}$ & Partial $^{k}$ \\
\hline Overall risk of bias & Low & Moderate & Moderate & Low & Low & Low \\
\hline
\end{tabular}

Notes: aWhile it is stated in the methods that this study was conducted prospectively, the limitations section states that it was retrospective; ${ }^{\text {bt }}$ is assumed that the study was conducted prospectively; however, it is unclear at times as some baseline data are missing; ' $H$ However, baseline CCS score was not described; IInsufficient baseline information provided; 'The process of CSRS implantation was not clearly described; 'Only efficacy measure was clearly established; 8 The two cardiologists performing the

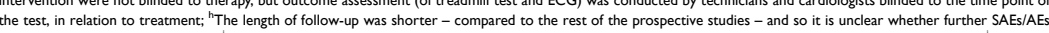
would show up at longer follow-up; 'It was reported that no SAEs occurred in the study population, yet AEs are not reported (and most presumably occurred); 'The study

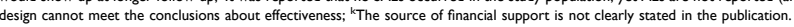

Moreover, it is unclear why there remains a $15-30 \%$ rate of non-responders. ${ }^{25}$ One assumption is that the lack of endothelialization may be at stake, ie that the surface of the device may not be completely covered by endothelium (the vein's inner lining) and thus may not create the pressure gradient. ${ }^{26}$ Another assumption is that anatomic variants of the cardiac venous system of individual patients may lead to insufficient pressure gradient across the device. ${ }^{25}$

Third, there is an echoing concern in the academic literature over the potential large placebo effect associated with novel therapies in this specific patient group. ${ }^{5,20,27}$ It is further highlighted that such a placebo effect may not result in steady long-term benefit ${ }^{20}$ and the short-term follow-up (6 months) of the only $\mathrm{RCT}^{13}$ does not prove otherwise.

Fourth, the clinical benefit caused by the CSRS may be overstated as the sample size in the RCT is not big enough to reject a true null hypothesis. ${ }^{28}$

Fifth, there is a concern in the literature over the randomization process in the RCT. ${ }^{13}$ It was highlighted that intravenous heparin was used only in IG patients and hence post-procedural laboratory testing may have revealed to the patients who belonged to the IG and who to the $\mathrm{CG}^{28}$

\section{Safety}

With regard to interpreting safety findings, underreporting of complications, obstruction of future therapy, and further potential SADEs need to be considered.

First, dual antiplatelet therapy (DAPT) with clopidogrel and aspirin is recommended for 6 months after the implantation of a CSRS. ${ }^{27}$ The complications related to DAPT are, however, not reported in the studies, even though they should be considered along with CSRS complications. While only two studies reported the use of DAPT, ${ }^{13,18}$ no studies reported on the SADE of bleeding events associated with DAPT.

Second, because heart failure may eventually develop in a large proportion of refractory AP patients, there is a concern that the CSRS may preclude the future use of the coronary sinus for implantation of the left ventricular pacing lead necessary for cardiac resynchronization therapy (CRT) (the established heart failure therapy). ${ }^{28}$

Third, potential SADEs related to individual anatomic considerations during implantation should be taken into account. The potential SADEs are related to the close proximity of the circumflex coronary artery, which may provoke an acute MI (if damaged), and the presence of a Thebesian valve or a valve of Vieussens, which could hamper device implantation in up to $85 \%$ of patients. ${ }^{29}$

\section{External Validity}

In terms of external validity, the data are considered not to be generalizable to other contexts as the CSRS patient population did not actually include refractory AP patients. Application of the highly specific inclusion and exclusion criteria in the real-world context also remains in question. Hence, in the light of the small population size and the selective sample of included patients, the conclusions about effectiveness and safety are considered inflated.

\section{Limitations of Evidence}

Owing to the limitations concerning the internal as well as external validity of the evidence base, it remains a question to what extent the RCT identified by our systematic literature 


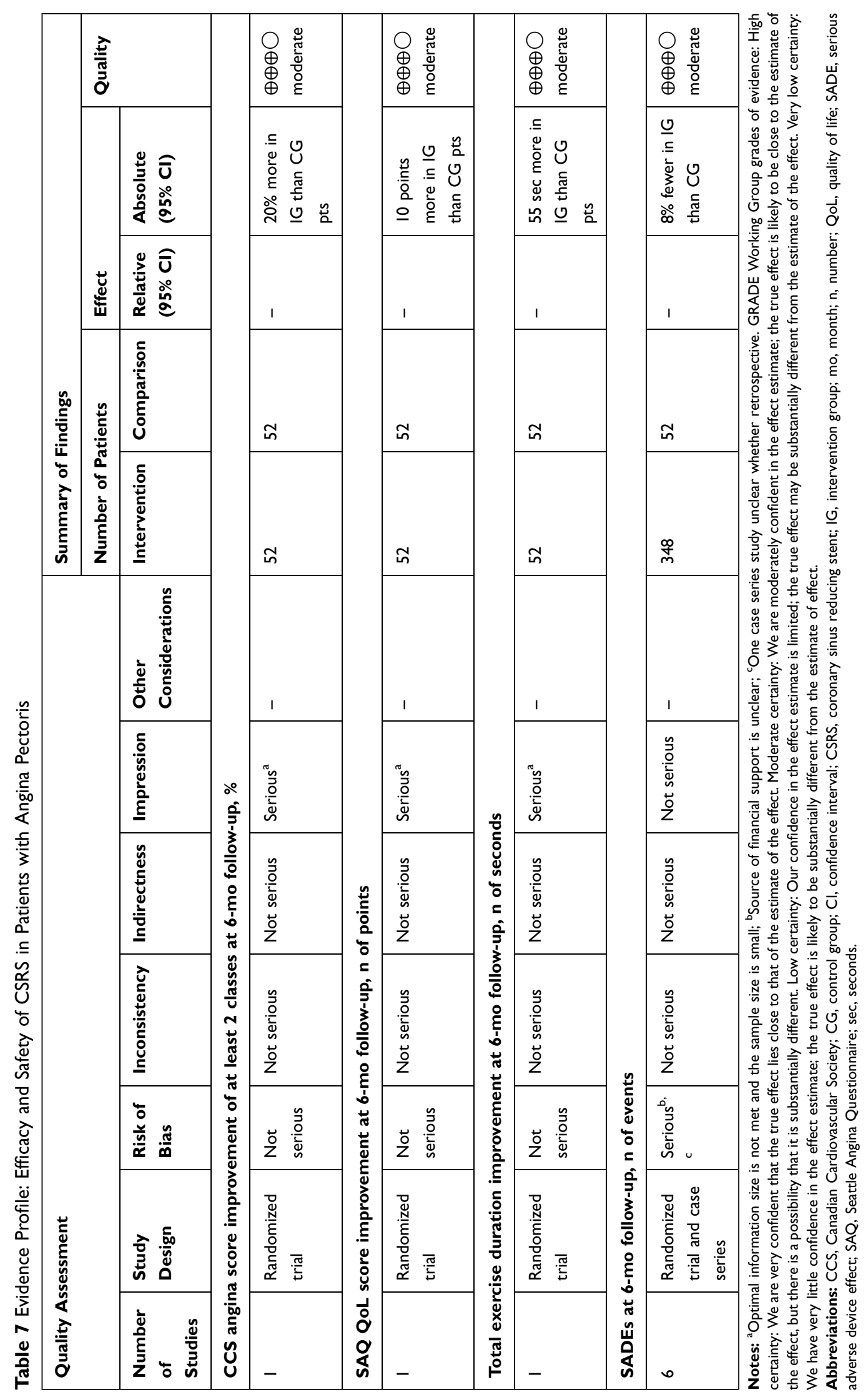


search is relevant for excluding placebo effects. Moreover, this result is further undermined by the large placebo effect associated with novel therapies in this specific patient population. ${ }^{5}$ Better powered RCTs with longer follow-up are needed for the sake of defining the role of treatment modalities for specific subgroups, for decreasing non-responder rates, and for ascertaining benefits beyond placebo effects. ${ }^{5}$

\section{Socio-Economic and Ethical Considerations}

When taking into consideration socio-economic and ethical aspects of the CSRS, the effects have to be reflected against the backdrop of principles of distributive justice, beneficence, non-maleficence, autonomy, and uncertainty. On the one hand, the CSRS is claimed to reduce healthcare spending as it decreased healthcare resource use and related costs in a 1-year timeframe under a spectrum of cost-effectiveness thresholds. ${ }^{30}$ Moreover, the CSRS targets a patient population where there is a therapeutic gap ${ }^{5}$ and so, if proven to be effective, the CSRS may secure the principles of medical beneficence and patient autonomy.

On the other hand, though, there is a lack of clarity behind the mechanism of action and there are no long-term data. ${ }^{20}$ There are further concerns of additional SADEs highlighted above that can, for instance, impede the use of CRT for future heart failure patients. ${ }^{28}$ For that reason, as stated above, to prevent breaching the principle of non-maleficence, better powered controlled trials are required. At this point in time, there is no larger RCT in the pipeline. The only RCT that is currently recruiting includes 40 patients and aims to measure the impact of the CSRS on exertional capacity measured by maximal oxygen consumption $\left(\mathrm{VO}_{2}\right)$ during cardiopulmonary exercise testing; it aims to be completed by December 2021 (NCT04121845). Important to note is that there is an ongoing ISCHEMIA trial (NCT01471522) that may potentially determine the best management strategy for higher-risk patients with stable ischemic heart disease, and may change the guideline for refractory AP patients considerably.

\section{Conclusion}

It is not clear whether the CSRS can improve CCS angina score and QoL without causing more SADEs than the sham intervention (based on moderate quality of evidence). This is because of inconsistent results, incomplete safety data with regard to DAPT, inappropriate inclusion criteria in the studies, insufficient sample size, and incomplete blinding in the RCT. The potential of the CSRS to fulfill the therapeutic gap ought to be considered against the backdrop of its unclear mechanism of action, the lack of a long-term safety profile, and additional potential SADEs. Furthermore, the cost-effectiveness of the CSRS can only be established once the effectiveness of CSRS is established. In that respect, owing to the inconsistencies with internal and external validity of the evidence base, even the conclusions about placebo effects cannot be taken for granted.

\section{Disclosure}

Piotr Szymanski reports personal fees from Abbott Laboratories as a speaker, not related to coronary stenting. The authors report no other conflicts of interest in this work.

\section{References}

1. Roth GA, Johnson C, Abajobir A, et al. Global, regional, and national burden of cardiovascular diseases for 10 causes, 1990 to 2015. J Am Coll Cardiol. 2017;70:25. doi:10.1016/j.jacc.2017.04.052

2. Mannheimer C. The problem of chronic refractory angina. Report from the ESC Joint Study Group on the Treatment of Refractory Angina. 2002.

3. Gowdak LHW. Prevalence of refractory angina in clinical practice. Heart Metab. 2017;72:9-12.

4. Simons M, Laham RJ. New therapies for angina pectoris. UpToDate; 2019. Available from: https://www.uptodate.com/contents/new-thera pies-for-angina-pectoris.

5. Knuuti J, Wijns W, Saraste A, et al. 2019 ESC guidelines for the diagnosis and management of chronic coronary syndromes: the Task Force for the diagnosis and management of chronic coronary syndromes of the European Society of Cardiology (ESC). Eur Heart J. 2019;41(3):407-477.

6. Benedetto D, Abawi M, Stella PR, et al. Percutaneous device to narrow the coronary sinus: shifting paradigm in the treatment of refractory angina? A review of the literature. Front. 2016;3:42.

7. Bazoukis G, Brilakis ES, Tse G, et al. The efficacy of coronary sinus reducer in patients with refractory angina-A systematic review of the literature. J Interv Cardiol. 2018;31(6):775-779.

8. Higgins J, Altman DG, Gøtzsche PC, et al. The Cochrane Collaboration's tool for assessing risk of bias in randomised trials. BMJ. 2011;343:d5928. doi:10.1136/bmj.d5928

9. Institute of Health Economics (IHE). Quality appraisal of case series studies checklist. Edmonton (AB): Institute of Health Economics; 2014. Available from: http://www.ihe.ca/research-programs/rmd/ cssqac/cssqac-about.

10. Stanak M, Rothschedl E. Percutaneous Transvascular Implantation of a Coronary Sinus Reducing Stent. Systematic Review. Decision Support Document No. 121; 2020. Vienna: Ludwig Boltzmann Institute for Health Technology Assessment. Available from: https:// eprints.aihta.at/1256/1/DSD_121.pdf. Accessed August 18, 2020

11. Balshem H, Helfand M, Schünemann HJ, et al. GRADE guidelines: 3. Rating the quality of evidence. J Clin Epidemiol. 2011;64(4):401406. doi:10.1016/j.jclinepi.2010.07.015

12. Higgins JPT, Green S, editors. Cochrane Handbook for Systematic Reviews of Interventions Version 5.1.0. The Cochrane Collaboration; 2011. 
13. Verheye S, Jolicoeur EM, Behan MW, et al. Efficacy of a device to narrow the coronary sinus in refractory angina. $N$ Engl $J$ Med. 2015;372(6):519-527. doi:10.1056/NEJMoa1402556

14. Tzanis G, Palmisano A, Gallone G, et al. The impact of the coronary sinus reducer upon left ventricular function in patients with refractory angina pectoris. Catheter Cardiovasc Interv. 2019; 95(6):1104-1108.

15. Ponticelli F, Tzanis G, Gallone G, et al. Safety and efficacy of coronary sinus reducer implantation at 2-year follow-up. Int $J$ Cardiol. 2019;292:87-90. doi:10.1016/j.ijcard.2019.05.026

16. Konigstein M, Meyten N, Verheye S, Schwartz M, Banai S. Transcatheter treatment for refractory angina with the coronary sinus reducer. EuroIntervention. 2014;9(10):1158-1164. doi:10.4244/EIJV9I10A196

17. Konigstein M, Bazan S, Revivo M, Banai S. Coronary sinus reducer implantation improves symptoms, ischaemia and physical capacity in patients with refractory angina unsuitable for myocardial revascularisation: a single-centre experience. EuroIntervention. 2018;14(4): e452-e8. doi:10.4244/EIJ-D-18-00102

18. Giannini F, Baldetti L, Ponticelli F, et al. Coronary Sinus Reducer Implantation for the Treatment of Chronic Refractory Angina: A SingleCenter Experience. JACC Cardiovasc Interv. 2018;11(8):784-792.

19. Banai S, Ben Muvhar S, Parikh KH, et al. Coronary sinus reducer stent for the treatment of chronic refractory angina pectoris: a prospective, open-label, multicenter, safety feasibility first-in-man study. $J$ Am Coll Cardiol. 2007;49(17):1783-1789. doi:10.1016/j.jacc.2007.01.061

20. Giannini F, Baldetti L, Konigstein M, et al. Safety and efficacy of the reducer: A multi-center clinical registry - REDUCE study. Int $J$ Cardiol. 2018;269:40-44.

21. Institute of Health Economics (IHE). Quality Appraisal of Case Series Studies Checklist. Edmonton (AB): Institute of Health Economics; 2014. Available from: http://www.ihe.ca/research-pro grams/rmd/cssqac/cssqac-about.
22. De Maria GL, Kassimis G, Raina T, Banning AP. Reconsidering the back door approach by targeting the coronary sinus in ischaemic heart disease. Heart. 2016;102(16):1263. doi:10.1136/heartjnl-2016-309642

23. Mohl W, Punzengruber C, Moser M, et al. Effects of pressure-controlled intermittent coronary sinus occlusion on regional ischemic myocardial function. $J$ Am Coll Cardiol. 1985;5(4):939-947. doi:10.1016/S0735-1097(85)80437-X

24. Kato S, Saito N, Nakachi T, et al. Stress perfusion coronary flow reserve versus cardiac magnetic resonance for known or suspected CAD. J Am Coll Cardiol. 2017;70(7):869-879. doi:10.1016/j.jacc.20 17.06.028

25. Giannini F, Gallone G, Baldetti L, et al. Reply to: "Coronary sinus reducer for the treatment of refractory angina". Int $J$ Cardiol. 2019;276:42. doi:10.1016/j.ijcard.2018.11.088

26. Zivelonghi C, Vermeersch G, Verheye S, Agostoni P. Incomplete coronary sinus reducer endothelialization as potential mechanism of clinical failure. Catheter Cardiovasc Interv. 2019;94(1):120-122.

27. Konigstein M, Giannini F, Banai S. The reducer device in patients with angina pectoris: mechanisms, indications, and perspectives. Eur Heart J. 2018;39(11):925-933. doi:10.1093/eurheartj/ehx486

28. Banai S, Verheye S, Jolicoeur EM. A device to narrow the coronary sinus for angina. N Engl J Med. 2015;372(20):1967-1968.

29. Pizarro G, Sánchez-Quintana D, Cabrera JA. A device to narrow the coronary sinus for angina. N Engl J Med. 2015;372(20):1965-1966.

30. Gallone G, Armeni P, Verheye S, et al. Cost-effectiveness of the coronary sinus reducer and its impact on the healthcare burden of refractory angina patients. Eur Heart J Qual Care Clin Outcomes. 2019. doi:10.1093/ehjqcco/qcz027

31. Ludwig Boltzmann Institut für Health Technology Assessment (LBIHTA). Internes manual abläufe und methoden Vienna; 2020. Available from: http:/hta.lbg.ac.at/uploads/tableTool/UllCmsPage/ gallery/InternesManual_2.Auff.pdf.
Medical Devices: Evidence and Research

\section{Publish your work in this journal}

Medical Devices: Evidence and Research is an international, peerreviewed, open access journal that focuses on the evidence, technology, research, and expert opinion supporting the use and application of medical devices in the diagnosis, monitoring, treatment and management of clinical conditions and physiological processes. The identification of novel devices and optimal use of existing devices which will lead to improved clinical outcomes and more effective patient management and safety is a key feature of the journal. The manuscript management system is completely online and includes a very quick and fair peer-review system. Visit http:// www.dovepress.com/testimonials.php to read real quotes from published authors. 